\title{
Speech Production Changes with the Use of a Multichannel Cochlear Implant in a Postlingually Hearing Impaired Adult
}

\author{
Sandy Cummings \\ Emily Groenewald \\ René Hugo \\ Department of Communication Pathology \\ University of Pretoria \\ Lida Müller \\ Department of Speech Pathology and Audiology \\ University of Stellenbosch \\ Mike van der Linde \\ Department of Information Technology \\ Division of Academic Computing \\ University of Pretoria
}

\begin{abstract}
Profoundly deaf cochlear implant users provide an interesting population in which to assess the role of distorted auditory feedback in speech, since their electrically stimulated hearing is significantly different from normal hearing. The aim of the study was to evaluate, by means of spectrographic and listener analyses, the speech production changes in a postlingually deafened adult with the use of a multichannel cochlear implant over time, compared to that of hearing aids as well as no-amplification. The results indicated significant improvements in the use of suprasegmental speech features as well in the production of specific segmental features of speech.
\end{abstract}

\section{OPSOMMING}

Uitermatige dowe pasiënte met kogleêre inplantings vorm 'n interessante populasie waarby die invloed van versteurde ouditiewe terugvoer op spraak ondersoek kan word, aangesien elektries-gestimuleerde gehoor betekenisvol verskil van normale gehoor. Die doel ván die studie was 'n ondersoek na die invloed van 'n multikanaal kogleêre inplanting oor 'n verloop van tyd, in vergelyking met geen ouditiewe versterking en versterking dmv gehoorapparate op spraakproduksie van 'n postlinguale dowe volwássene. 'n Vergelykende spektrografiese en luisteraaranalise is uitgevoer. Die resultate het betekenisvolle verbeteringe getoon in die suprasegmentele, sowel as spesifieke segmentele eienskappe van spraak.

\section{INTRODUCTION}

Research on the benefits of cochlear implants have in the past focused primarily on the speech perception of the postlingually deafened implant user (Dowell, Brown, Seligman \& Clark, 1985; Dowell, Seligman, Blamey \& Clark, 1987; Eddington, 1983; Cohen, Waltzman \& Shapiro, 1985 and Schindler, Kessler, Rebscher, Yanda \& Jackler, 1986). Improvements in environmental sound recognition as well as improvements in auditory sensitivity (Thielemeir, Eisenberg \& Brimacombe, 1982; Tyler, Gantz, McCabe, Lowder, Otto $\&$ Preece, 1985) have also been widely documented. An increasing number of researchers have begun to place emphasis on the speech production characteristics of postlingually deafened implant wearers, (Iler-Kirk \& Edgerton, 1983; Leder, Spitzer, Milner, FlevarisPhillips, Richardson \& Kirchner, 1986; Tartter, Chute \& Hellman, 1989; Waldstein, 1990; Lane \& Webster, 1991; Economou, Tartter, Chute \& Hellman, 1992; Perkell, Lane, Svirsky \& Webster, 1992; Svirsky, Lane, Perkell \& Wosniak, 1992). The lack of research directed at the speech production changes could be due to the fact that a postlingually acquired deafness does not necessarily lead to problems of speech degeneration (Ling, 1976). Studies designed to investigate the speech 
characteristics of postlingually deaf subjects have, however, found that longterm total auditory deprivation in hearing adults resulted in eventual deterioration into flat, unmodulated and dysprosodic voice, (Cowie, Douglas-Cowie \& Kerr, 1982). Waldstein (1990) investigated some effects of postlingual deafness on speech by exploring selected properties of consonants, vowels and suprasegmentals in the speech of seven totally, postlingually deafened individuals. Their results demonstrated that postlingual deafness affects the production of all the classes of speech sounds. Re-introduction of "auditory input" with the electrical stimulation of the auditory nerve should result in changes in speech production. These changes in speech production are primarily reliant on the type of information derived from stimulation and finally the implant listener's articulatory adaptation to prolonged profound deafness, (Perkell et al., 1992).

The most common changes in speech production with the use of multichannel cochlear implants can be described in terms of suprasegmental and segmental changes, although previous studies have indicated that the suprasegmental features are affected the most due to the presence of a profound hearing loss, (Leder et al., 1986). Waldstein, (1990) indicated that the results of his study do not support the hypothesis that the suprasegmental properties of speech show the greatest effects of a loss of auditory feedback, while the segmental properties remain relatively unaffected. "Rather, auditory feedback appears to be implicated in monitoring and maintaining phonetic precision in all classes of speech sounds." Waldstein, (1990:211).

Various studies investigating the effects of multichannel cochlear implants on speech production have indicated that significant changes in speech production can occur with the use of a multichannel implant. Lane \& Webster, (1991) have reviewed some of the studies investigating the speech of postlingually deafened speakers including several studies on the effects of cochlear implants. They conclude that the majority of studies implicate a role for audition in regulating, directly or indirectly, several speech properties including voice quality, voice aspiration, vocal duration, pitch, intonation, stress, tempo, nasality and frication and plosive articulation, (Iler-Kirk \& Edgerton 1983; Leder et al., 1986; Tartter et al., 1989; Economou et al., 1992; Perkell et al., 1992).

\section{METHOD}

\section{AIMS}

The aim of the present study was to evaluate the speech production changes brought about by the use of a multichannel cochlear implant over time, in an adult with a profound postlingual sensorineural hearing loss. The subject's speech production skills were evaluated pre- and post-operatively by means of spectrographic and listener analyses. These evaluations included:

\footnotetext{
- the spectrographic evaluation of the suprasegmental features of speech, in terms of sentence duration, fundamental frequency variations and word stress (amplification).
}

the spectrographic evaluation of the segmental features of speech, namely vowels and consonants. The vowels were evaluated in terms of vowel length and the formant relationships between $F 1$ and $F 2$. The consonants were evaluated in terms of the spectral noise band frequencies for fricatives, the spectral frequency ranges for the plosive sections of the stop sounds and the relative amplitude peaks of both the fricatives and plosives.

- the listener's analysis of speech production was evaluated in terms of pitch variation, and vocal and pausal duration.

- the results of the speech production changes with the multichannel cochlear implant over time were compared to the subject's speech production without any amplification and with binaural hearing aids.

\section{RESEARCH METHODOLOGY}

A single-case research study using a time series experimental design was used in order to evaluate the speech production changes with the use of a multichannel cochlear implant in an adult with a postlingual sensorineural hearing loss. The data was obtained by performing evaluations in the following phases:

Pre-implant: No-amplification (NA); hearing aid (HA)

Post-implant: 0 -months (CI-0), 3-months (CI-3) and 6 -months (CI-6) cochlear implant

\section{SUBJECT}

The subject (MC) lost his hearing due to meningitis at 19 years of age. He was implanted five years later. His pre-implant audiograms indicated a bilaterally total sensorineural hearing loss with minimal benefit from binaural hearing aids as well as a vibrotactile device. His right ear was implanted on 31 October 1991 with the Cochlear 22-channel implant. All electrodes were easily inserted. The electrodes were programmed in the Bipolar + 1 mode using the MPEAK coding strategy. The subject (MC) was an Afrikaans speaker using a nonstandard dialect.

\section{IMPLANT AND SPEECH PROCESSOR}

The cochlear implant used in the present study is known as the Mini-System 22 comprising 22 pure platinum bands supported on a flexible silicone rubber carrier. The speech processor utilized is referred to as the MSP (Mini Speech Processor). The MPEAK coding strategy extracts and codes $F 1$ and F2, where the F1 is represented by the dominant spectral peak in the range from approximately $300-1000 \mathrm{~Hz}$ and $\mathrm{F} 2$ between 800 $4000 \mathrm{~Hz}$. The estimate of $\mathrm{F} 1$ from the acoustic signal controls the selection of an apical electrode pair, while the estimate of F2 controls the selection of a basal electrode pair. The spectral energy in the regions of 2000$2800 \mathrm{~Hz}, 2800-4000 \mathrm{~Hz}$ and above $4000 \mathrm{~Hz}$ are presented to three basally located electrodes. The fundamental or voicing frequency determines the pulse rate of the stimulation and the amplitude of the acoustic signal determines the stimulus intensity, (Cochlear, 1989). 


\section{HEARING AIDS}

The two Phonak PPC-L-4 hearing aids were utilized in the pre-implant evaluation condition. The maximum output of the hearing aids is $142 \mathrm{~dB}$ SSPL with a frequency range of $140-4900 \mathrm{~Hz}$. The subject used the hearing aid on volume 2,5 with the following settings: LC - 1, HC - 5, G - 6 and SSPL - 6. The subject also wore new standard acrylic ear moulds.

\section{STIMULI AND EQUIPMENT}

The data for the evaluation of the subject's speech production skills were determined objectively and subjectively by means of spectrographic and listener analyses respectively. For the spectrographic analysis of the suprasegmental features of speech, seven sentences varying in length and including the various typical prosodic features of statements, questions and commands, were selected to be spectrographically analyzed. For the spectrographic analysis of the segmental features, eight isolated single vowels; / i / / a $/,=/ \mathrm{y} /, / \infty / / \mathrm{u} /, /$ a $/$, / o / \& / / / in CVC combinations were selected to be analyzed. The vowels selected were the most common vowels utilized in Afrikaans where the transition to diphtongs does not take place. The consonants selected were those consonants which are either ommitted or distorted in the presence of a profound hearing loss (Nickerson, 1975). The plosives, / t/,/k/,/ p/and the fricatives $/ \mathrm{s} /$ and $/ \mathrm{x} /$ were used in the final position and $/ \mathrm{s} /$ and $/ \mathrm{f} /$ were used in the initial position of the word. These consonants were analyzed within the context of two different words and preceded or followed by different vowels. For the listener analysis, the subject was required to read a paragraph in which the length, language, content and complexity was appropriate for the purpose of the evaluation as well as the subject's reading skills.

The specified material was read into a Dynamic MO2 NCC microphone ( $15 \mathrm{~cm}$ from the microphone) in an IAC soundproof and sound reverberation free unit. The recordings were made on a Nachamitchi, model $6822 \mathrm{X}$ Direct Head Casette Deck? The speaker's distance from the microphone as well as the input attenuation were kept constant throughout all the recordings. Spectrographic analyses were conducted using the KAY DSP Sonagraph, Model 5500. The analysed data was graphically displayed on a: NEC/Multisync colour monitor.

\section{PROCEDURE}

\section{Recording of data}

Recordings of all the stimulus words and sentences were made without any amplification of the signal in the pre-implant condition, with binaural hearing aids in the pre-implant condition, the following day after switch-on i.e., 0 - months; 3 -months and 6 -months postimplant.

\section{Spectrographic analysis}

For the analysis of the suprasegmental features, a combination analysis setup of the sonagraph, whereby the waveform, amplitude and pitch trace of the sentences were displayed, was used for the measurements. The sentence duration was measured by applying time cursors on the speech wave display. Pitch variation was determined by using the frequency cursor readings on the computed pitch curves at the highest and lowest peaks in the pitch trace. Word stress or amplification was measured by the time cursors at the highest peak of computed amplitude curves.

The analysis of segmental features of specific speech sounds focused on the duration and formant frequencies of vowels and the spectral characteristics of the fricatives and the plosive energy of stop consonants. The vowels were analyzed up to $4000 \mathrm{~Hz}$ and the consonants up to $8000 \mathrm{~Hz}$. A combination display of a wideband spectrogram in conjunction with a narrowband amplitude spectrum of the computed spectral energy between two time cursors was used. Time cursors were used in order to determine the length of the vowel. For the measurements of the formant frequencies, a stable middle portion of each vowel was selected in order to exclude the transitions to the consonants. Frequency cursors, in conjunction with the time cursors were utilized in order to determine the formant frequencies.

The consonants were analyzed in terms of the spectral noise band frequencies for the fricatives (i.e., minimum and maximum frequencies of the fricatives), the spectral frequency range for the plosive sections of the stop sound (i.e., minimum and maximum frequencies of the plosive sections of the stop sounds) and the relative amplitude peaks of the fricatives and plosives. Time and frequency cursors were used to determine the frequency boundaries as well as the relative amplitude peaks.

\section{Listener analysis}

For the listener's evaluation of the subject's speech production, a rating scale for listener's evaluation of pitch variation and vocal and pausal duration was used, (Coles, 1990). The recordings were presented to four trained listeners via Tandberg Educational headphones in a language laboratory by means of a Tandberg Educational IS 10 cassette player. The listeners were asked to evaluate pitch variation, vocal duration and pausal duration by means of a five point rating scale (Appen$\operatorname{dix} \mathrm{A}$ ).

\section{RESULTS}

\section{RESULTS OF THE SPEECH PRODUCTION EVALUATION USING SPECTROGRAPHIC ANALY- SIS.}

It is important to note that there were no marked abnormal characteristics pertaining to the subject's suprasegmental and segmental features as found in some postlingually deafened adults. Spectrographic analyses were executed in order to detect any degeneration of speech features which had possibly occurred during the period of profound deafness as well as any changes in speech production brought about by the use of the cochlear implant. 


\section{Suprasegmental features}

The results of sentence duration across various auditory input situations are presented in Table 1 .

When analyzed, the majority of the sentences showed an increase in sentence duration at the six month cochlear implant level, as opposed to the no-amplification and hearing aid conditions. The increases in sentence duration occurred at either the cochlear implant 0 -month or 3-month situation, with a highest mean duration for the seven sentences at 0 -months. A qualitative analysis of the individual sentences does, however, give logical explanations for these results. The interpretation and explanation of the above findings will be given in the discussion of results.

As can be seen in Table 2, the highest relative amplitude peaks for stressed words showed a small, however, consistent increase in the amplitude range with the use of the cochlear implant, with the values ranging from $33,1 \mathrm{~dB}, 37,4 \mathrm{~dB}$ and $37 \mathrm{~dB}$ during the $0-, 3-$ and 6 -month cochlear implant intervals, compared to $31,7 \mathrm{~dB}$ and $34 \mathrm{~dB}$ obtained during the no-amplification and hearing aid conditions respectively. The values for all sentences obtained during the 3 -month interval showed an increase in amplitude peaks when compared to the 0 . month interval. During the 6-month interval, however, there was a slight decrease in amplitude peaks for sentences two, four and six when compared to the 3 -month cochlear implant interval. These values compared to the 0 -month interval did, however, show an increase in amplitude range.

The results of the fundamental frequency (FO) variations, including the minimum and maximum $F 0$ values as well as the differences in $\mathrm{F} 0$ across the various auditory input situations, are presented in Table 3 .

As can be seen in Table 3 , the mean difference in fundamental frequency variations for the no-amplification $(49,7 \mathrm{~Hz})$ and hearing aid $(48,7 \mathrm{~Hz})$ situations did not differ significantly from one another. Surprisingly, the results for the 0 -month cochlear implant interval showed a decrease in $\mathrm{F} 0$ variation $(44,4 \mathrm{~Hz})$. A significant increase in the mean $F 0$ variation occurred at the 3 -month interval $(110,7 \mathrm{~Hz})$, indicating a possible over compensation in the use of varying $\mathrm{F} 0$. The results obtained at the 6-month interval $(86,5 \mathrm{~Hz})$ also showed an increase in $\mathrm{FO}$ variation when compared to the no-amplification and hearing aid situations, however, the variation was less and possibly more normalized, than observed during the 3 -month interval.

\section{Segmental features}

\section{- Vowels}

Due to variations in vowel duration for each of the vowels within the three cochlear implant evaluation intervals, a mean vowel duration for each of the eight vowels during the cochlear implant intervals was calculated. The results of the evaluation of vowel duration presented in Table 4, did not indicate significant

Table 1. Sentence duration (seconds) for sentences across various auditory input situations.

\begin{tabular}{|c|c|c|c|c|c|c|}
\hline $\begin{array}{c}\text { Sentence } \\
\text { number }\end{array}$ & N.A. & H.A. & CI-O & CI-3 & CI-6 & $\begin{array}{c}\text { Mean values } \\
\text { CI } 0,3,6\end{array}$ \\
\hline 1 & 0,8719 & 0,9750 & 0,9937 & 0,9031 & 0,8844 & 0,927 \\
\hline 2 & 1,153 & 1,272 & 1,438 & 1,472 & 1,387 & 1,432 \\
\hline 3 & 1,700 & 1,727 & 2,425 & 1,993 & 1,878 & 2,098 \\
\hline 4 & 1,537 & 1,691 & 1,628 & 1,600 & 1,547 & 1,591 \\
\hline 5 & 1,237 & 1,575 & 1,456 & 1,359 & 1,322 & 1,379 \\
\hline 6 & 0,9469 & 0,9688 & 0,9562 & 1,031 & 0,9312 & 0,972 \\
\hline 7 & 0,8031 & 0,9600 & 1,006 & 0,9750 & 0,9125 & 0,964 \\
\hline
\end{tabular}

Table 2. Highest amplitude peaks (dB) for stressed words in sentences across various auditory input situations.

\begin{tabular}{|c|c|c|c|c|c|}
\hline Sentence number & N.A & H.A & CI-0 & CI-3 & CI-6 \\
\hline 1 & 25 & 35 & 33 & 37 & 37 \\
\hline 2 & 24 & 32 & 30 & 37 & 35 \\
\hline 3 & 37 & 34 & 31 & 36 & 37 \\
\hline 4 & 34 & 30 & 33 & 36 & 35 \\
\hline 5 & 34 & 34 & 37 & 40 & 41 \\
\hline 6 & 33 & 35 & 32 & 39 & 37 \\
\hline 7 & 35 & 38 & 36 & 37 & 37 \\
\hline
\end{tabular}


differences between the various auditory input situations. For all the vowels examined except for the vowel $/ y /$, however, when a mean value for the $0-, 3$ - and 6 month evaluations was calculated, the latter did show a decrease in vowel duration when compared to either the no-amplification or hearing aid condition.

The formant frequencies of the vowels analyzed, i.e., F1 and F2, presented in Table 5, did not differ from one another significantly across the various auditory input situations. Compared to the normal values of F1 and F2 in the vowels of male Afrikaans speakers, (Van der Merwe, Groenewald, Van Aardt, Tesner \& Grimbeek, 1993), the formant frequencies of four of the vowels i.e. $/ \mathrm{i} /, / \mathrm{a} / \mathrm{l}=/ \mathrm{u} /$ and $/ \varepsilon /$ fell within the normal limits. In the four remaining vowels i.e. $/ \propto /, / \rho /$ and $/ œ /$ examined except for $/ y /$, the $F 2$ values fell within the normal limits for these vowels. The F1 values, however, were measured at higher frequencies than the normal limits for F1. The results in the present study did, however, indicate that the $\mathrm{F} 1$ and $\mathrm{F} 2$ values did remain relatively consistent across the various auditory input situations as was observed with the other four vowels examined.

\section{- Consonants}

As can be seen in Table 6 for the majority of the consonants examined in the present study, the use of the cochlear implant did show an increase in the relative amplitude peaks measured for consonant production i.e., plosives and fricatives. The relative amplitude peaks for the consonants in the various auditory input situations ranged from $0-46 \mathrm{~dB}$ in the no-amplification situation, 0-50dB in the hearing aid situation, $19-51 \mathrm{~dB}$ in

Table 3. Minimum and maximum fundamental frequency values (Fo-Hz) and difference in fundamental frequency $(\Delta \mathrm{Fo})$ for sentences across various auditory input situations.

\begin{tabular}{|c|c|c|c|c|c|c|c|c|c|c|c|}
\hline $\begin{array}{l}\text { Sentence } \\
\text { number }\end{array}$ & $\begin{array}{l}\text { Max Fo } \\
\text { Min Fo }\end{array}$ & N.A & $\begin{array}{l}\text { N.A } \\
\Delta F_{0}\end{array}$ & H.A & $\begin{array}{l}\text { H.A } \\
\Delta \mathrm{Fo}^{\circ}\end{array}$ & CI-0 & $\begin{array}{l}\mathrm{CI}-0 \\
\triangle \mathrm{Fo}\end{array}$ & CI-3 & $\begin{array}{l}\mathrm{CI}-3 \\
\triangle \mathrm{Fo}\end{array}$ & CI-6 & $\begin{array}{l}\text { CI-6 } \\
\Delta \text { Fo }\end{array}$ \\
\hline \multirow[t]{2}{*}{1} & $\operatorname{Max}$ & 162 & \multirow[t]{2}{*}{45} & 157 & \multirow[t]{2}{*}{70} & 134 & \multirow[t]{2}{*}{34} & 243 & \multirow[t]{2}{*}{137} & 222 & \multirow[t]{2}{*}{103} \\
\hline & Min & 117 & & 87 & & 100 & & 106 & & 119 & \\
\hline \multirow[t]{2}{*}{2} & Max & 132 & \multirow[t]{2}{*}{43} & 129 & \multirow[t]{2}{*}{45} & 124 & \multirow[t]{2}{*}{38} & 204 & \multirow[t]{2}{*}{113} & 182 & \multirow[t]{2}{*}{80} \\
\hline & Min & 89 & & 84 & & 86 & & 91 & & 102 & \\
\hline \multirow[t]{2}{*}{3} & $\operatorname{Max}$ & 170 & \multirow[t]{2}{*}{89} & 150 & \multirow[t]{2}{*}{62} & 129 & \multirow[t]{2}{*}{48} & 213 & \multirow[t]{2}{*}{115} & 213 & \multirow[t]{2}{*}{89} \\
\hline & $\operatorname{Min}$ & 81 & & 88 & & 81 & & 98 & & 124 & \\
\hline \multirow[t]{2}{*}{4} & Max & 144 & \multirow[t]{2}{*}{28} & 128 & \multirow[t]{2}{*}{30} & 138 & \multirow[t]{2}{*}{35} & 182 & \multirow[t]{2}{*}{56} & 186 & \multirow[t]{2}{*}{69} \\
\hline & Min & 116 & & 98 & & 103 & & 126 & & 117 & \\
\hline \multirow[t]{2}{*}{5} & $\operatorname{Max}$ & 179 & \multirow[t]{2}{*}{73} & 165 & \multirow[t]{2}{*}{72} & 186 & \multirow[t]{2}{*}{89} & 262 & \multirow[t]{2}{*}{176} & 256 & \multirow[t]{2}{*}{149} \\
\hline & Min & 106 & & 93 & & 97 & & 86 & & 107 & \\
\hline \multirow[t]{2}{*}{6} & $\mathrm{Ma}_{1}^{\prime} \mathbf{x}$ & 144 & \multirow[t]{2}{*}{27} & 142 & \multirow[t]{2}{*}{42} & 124 & \multirow[t]{2}{*}{23} & 196 & \multirow[t]{2}{*}{79} & 165 & 54 \\
\hline & $\mathrm{Min}_{i}$ & 117 & & 100 & & 101 & & 117 & & 111 & \\
\hline 7 & $\mathrm{Max}$ & 162 & 43 & 167 & 60 & 144 & 44 & 222 & 99 & 204 & 62 \\
\hline & Mín & 119 & & 107 & & 100 & & 123 & & 142 & \\
\hline $\begin{array}{l}\text { Mean difference } \\
\text { in Fo }\end{array}$ & & & 49,7 & & 54,4 & & 44,4 & & 110,7 & & 86,5 \\
\hline
\end{tabular}

Table 4. Vowel duration (seconds) for vowels across various auditory input situations

\begin{tabular}{|c|c|c|c|c|c|c|c|}
\hline Word & Vowel & N.A. & H.A. & CI-0 & CI-3 & CI-6 & Mean \\
\hline mier & $/ \mathrm{i} /$ & 0,4812 & 0,4016 & 0,4187 & 0,2469 & 0,3125 & 0,3260 \\
\hline waak & $/ \mathrm{a} /$ & 0,2187 & 0,3719 & 0,2813 & 0,3875 & 0,3562 & 0,3416 \\
\hline duur & $/ \mathrm{y} /$ & 0,3375 & 0,3156 & 0,4812 & 0,3312 & 0,4590 & 0,4238 \\
\hline dop & $/ \mathrm{J} /$ & 0,1469 & 0,1344 & 0,1500 & 0,1312 & 0,1094 & 0,1302 \\
\hline toer & $/ \mathrm{d}$ & 0,5875 & 0,5594 & 0,4906 & 0,4094 & 0,4031 & 0,4343 \\
\hline pen & $/ \mathrm{g} /$ & 0,1656 & 0,1563 & 0,1781 & 0,1187 & 0,1156 & 0,1374 \\
\hline rug & $/ \mathrm{e} /$ & 0,1219 & 0,1656 & 0,1594 & 0,1281 & 0,1563 & 0,1479 \\
\hline mis & $/ \mathrm{/} /$ & 0,0781 & 0,1312 & 0,1344 & 0,0962 & 0,0734 & 0,1013 \\
\hline
\end{tabular}


Table 5. Formant frequencies - $H_{2}\left(F_{1} / F_{2}\right)$ for vowels across various auditory input situations

\begin{tabular}{|c|c|c|c|c|c|c|c|c|c|}
\hline Word & Vowel & $F_{1} / F_{2}$ & N.A & H.A & CI-0 & CI-3 & CI-6 & $\begin{array}{c}\text { Mean } \\
\text { Ci } 0,3,6\end{array}$ & $\begin{array}{c}\text { Normal } \\
\mathbf{F}_{1} / \mathbf{F}_{2}\end{array}$ \\
\hline \multirow[t]{2}{*}{ mier } & /i/ & $\mathrm{F}_{1}$ & 300 & 260 & 300 & 300 & 280 & 293 & 245 \\
\hline & & $\mathrm{F}_{2}$ & 2180 & 2190 & 2160 & 2320 & 2380 & 2287 & 2186 \\
\hline \multirow[t]{2}{*}{ waak } & (a) & $F_{1}$ & 760 & 620 & 770 & 640 & 600 & 670 & 679 \\
\hline & & $\mathrm{F}_{2}$ & 1180 & 1160 & 1180 & 1220 & 1060 & 1153 & 1113 \\
\hline \multirow[t]{2}{*}{ duur } & $|y|$ & $\mathrm{F}_{1}$ & 260 & 240 & 220 & 390 & 290 & 300 & $*$ \\
\hline & & $\mathbf{F}_{2}$ & 2180 & 2160 & 2080 & 2310 & 2470 & 2287 & $*$ \\
\hline \multirow[t]{2}{*}{ dop } & $/ \alpha$ & $\mathrm{F}_{1}$ & 580 & 280 & 540 & 540 & 590 & 557 & 373 \\
\hline & & $\mathrm{F}_{2}$ & 1020 & 1080 & 1180 & 1040 & 1040 & 1087 & 805 \\
\hline \multirow[t]{2}{*}{ toer } & $/ \mathrm{u} /$ & $F_{1}$ & 260 & 250 & 260 & 390 & 360 & 337 & 266 \\
\hline & & $\mathrm{F}_{2}$ & 780 & 920 & 780 & 800 & 1010 & 863 & 961 \\
\hline \multirow[t]{2}{*}{ pen } & $/ \varepsilon /$ & $\mathbf{F}_{1}$ & 500 & 480 & 500 & 560 & 530 & 530 & 353 \\
\hline & & $\mathrm{F}_{2}$ & 1960 & 2040 & 2060 & 2100 & 2000 & 2053 & 2055 \\
\hline \multirow[t]{2}{*}{ rug } & $/ œ /$ & $\mathrm{F}_{1}$ & 640 & 540 & 560 & 580 & 580 & 573 & 429 \\
\hline & & $\mathbf{F}_{2}$ & 1280 & 1200 & 1240 & 1160 & 1040 & 1147 & 1314 \\
\hline \multirow[t]{2}{*}{ mis } & $\mid a /$ & $F_{1}$ & 580 & 540 & 540 & 540 & 600 & 560 & 507 \\
\hline & & $\mathrm{F}_{2}$ & 1400 & 1520 & 1480 & 1470 & 1330 & 1427 & 1514 \\
\hline
\end{tabular}

Table 6: Relative amplitude peaks (dB) for consonants in CVC word combinations across various auditory input situations

\begin{tabular}{|c|c|c|c|c|c|c|c|}
\hline Word & Consonant & Position & No amplification & Hearing Aid & $\begin{array}{c}\text { CI } \\
0 \\
\text { months }\end{array}$ & $\begin{array}{c}\text { CI } \\
3 \\
\text { months }\end{array}$ & $\begin{array}{c}\text { CI } \\
6 \\
\text { months }\end{array}$ \\
\hline lied & $/ \mathrm{t} /$ & Final & 0 & 38 & 23 & 35 & 48 \\
\hline pit & $/ \mathrm{t} /$ & Final & 29 & 18 & 31 & 47 & 48 \\
\hline loop & $/ \mathrm{p} /$ & Final & 0 & 19 & 22 & 23 & 21 \\
\hline druip & $/ \mathrm{p} /$ & Final & 0 & 0 & 19 & 31 & 29 \\
\hline bek & $/ \mathbf{k} /$ & Final & 26 & 0 & 20 & 37 & 39 \\
\hline rok & $/ \mathbf{k} /$ & Final & 0 & 20 & 21 & 33 & 36 \\
\hline kous & $/ \mathrm{s} /$ & Final & 31 & 43 & 48 & 44 & 48 \\
\hline $\operatorname{mos}$ & $/ \mathrm{s} /$ & Final & 44 & 43 & 48 & 44 & 49 \\
\hline rug & $/ \mathbf{x} /$ & Final & 33 & 43 & 27 & 38 & 36 \\
\hline saag & $|x|$ & Final & 29 & 35 & 34 & 33 & 31 \\
\hline sag & $/ \mathrm{s} /$ & Initial & 43 & 50 & 51 & 29 & 54 \\
\hline saag & $/ \mathrm{s} /$ & Initial & 46 & 48 & 48 & 54 & 52 \\
\hline vaak & $/ \mathbf{f} /$ & Initial & 19 & 34 & 22 & 34 & 28 \\
\hline vuur & $/ f /$ & Initial & 33 & 34 & 26 & 29 & 32 \\
\hline
\end{tabular}


the 0-month cochlear implant interval, 23-54dB in the 3-month interval and 21-54dB in the 6-month interval. Three of the consonant productions in the final position i.e., $/ \mathrm{t} / \mathrm{l} / \mathbf{k} / \mathrm{and} / \mathbf{p} /$ were not produced with any audible plosive release in the no-amplification and hearing aid situations therefore having no measurable amplitude peaks i.e., $0 \mathrm{~dB}$.

The results of the mean spectral frequency ranges for the plosive energy of the plosives i.e., / $t /, / p /$, and / $\mathbf{k}$ $/$ and the spectral noise band frequencies for the fricatives i.e., $/ \mathrm{s} /$,

$/ \mathrm{x} /$ and $/ \mathrm{f} /$, presented in Table 7 , did show a narrowing of these frequency ranges for the majority of consonants evaluated in the three cochlear implant intervals when compared to the hearing aid conditions. Once again there were no measurable spectral frequency ranges $(0 \mathrm{~Hz})$ for three of the consonants i.e., $/ \mathrm{p} /, / \mathrm{t} /$ and $/ \mathbf{k} /$, as there was no audible plosive release in the final position during the no-amplification and hearing aid conditions.

\section{Results of the speech production evaluation using listener analysis.}

The results of the listener's evaluation of the subject's speech production are presented in Table 8 . The trained listeners rated the subject's spontaneous speech at the various auditory input situations, according to the rating scale used. These ratings occurred in a language laboratory.

As can be seen in Table 8 the listeners rated the subject's use of pitch variation as being monotone in the no-amplification, hearing aid and 0 -month cochlear implant conditions. At the 3-month cochlear implant interval, the listeners rated the subject's speech as having little variation and the 6 -month cochlear implant interval the listeners rated the subject's use of pitch variation as being normal. With regard to vocal dura. tion, the listeners evaluated the subject's vocal duration in the no-amplification, hearing aid and cochlear implant 0 -month interval as being longer than normal.

Table 7. Minimum and maximum frequencies for consonants in CVC word combinations across various auditory input situations.

\begin{tabular}{|c|c|c|c|c|c|c|c|c|}
\hline Word & Consonant & Position & $\begin{array}{l}\text { Minimum } \\
\text { maximum }\end{array}$ & No Amp & $\mathrm{HA}$ & CI-0 & CI-3 & CI-6 \\
\hline lied & $/ \mathrm{t} /$ & Final & $\begin{array}{l}\text { Min } \\
\operatorname{Max}\end{array}$ & $\begin{array}{l}0 \\
0\end{array}$ & $\begin{array}{c}1760 \\
8000^{+}\end{array}$ & $\begin{array}{l}2460 \\
4900\end{array}$ & $\begin{array}{c}1680 \\
8000^{+}\end{array}$ & $\begin{array}{l}2880 \\
6040\end{array}$ \\
\hline pit & $/ \mathrm{t} /$ & Final & $\begin{array}{l}\text { Min } \\
\operatorname{Max}\end{array}$ & $\begin{array}{l}3440 \\
6800 \\
\end{array}$ & $\begin{array}{l}1760 \\
3160 \\
\end{array}$ & $\begin{array}{c}2480 \\
8000^{+}\end{array}$ & $\begin{array}{c}2720 \\
8000^{+}\end{array}$ & $\begin{array}{c}3400 \\
8000^{+}\end{array}$ \\
\hline loop & $/ \mathrm{p} /$ & Final & $\begin{array}{l}\text { Min } \\
\operatorname{Max}\end{array}$ & $\begin{array}{l}0 \\
0\end{array}$ & $\begin{array}{l}3560 \\
4720\end{array}$ & $\begin{array}{c}1080 \\
8000^{+}\end{array}$ & $\begin{array}{l}1160 \\
7960\end{array}$ & $\begin{array}{l}3680 \\
6440\end{array}$ \\
\hline druip & $/ \mathrm{p} /$ & Final & $\begin{array}{l}\text { Min } \\
\text { Max }\end{array}$ & $\begin{array}{l}0 \\
0\end{array}$ & $\begin{array}{l}0 \\
0 \\
\end{array}$ & $\begin{array}{c}1040 \\
8000^{+}\end{array}$ & $\begin{array}{c}1240 \\
8000^{+}\end{array}$ & $\begin{array}{c}980 \\
8000^{+}\end{array}$ \\
\hline bek & $/ \mathrm{k} /$ & Final & $\begin{array}{l}\text { Min } \\
\operatorname{Max}\end{array}$ & $\begin{array}{c}880 \\
8000^{+}\end{array}$ & $\begin{array}{l}0 \\
0 \\
\end{array}$ & $\begin{array}{l}1060 \\
5000\end{array}$ & $\begin{array}{c}960 \\
5600\end{array}$ & $\begin{array}{c}880 \\
6240\end{array}$ \\
\hline rok & $/ \mathbf{k} /$ & Final & $\begin{array}{l}\text { Min } \\
\text { Max }\end{array}$ & $\begin{array}{l}0 \\
0 \\
\end{array}$ & $\begin{array}{c}960 \\
4280 \\
\end{array}$ & $\begin{array}{c}880 \\
5020 \\
\end{array}$ & $\begin{array}{c}680 \\
8000^{+}\end{array}$ & $\begin{array}{c}640 \\
3680\end{array}$ \\
\hline kous & $/ \mathrm{s} /$ & Final & $\begin{array}{l}\text { Min } \\
\operatorname{Max}\end{array}$ & $\begin{array}{c}2420 \\
8000^{+}\end{array}$ & $\begin{array}{c}2240 \\
8000^{+}\end{array}$ & $\begin{array}{c}2500 \\
8000^{+}\end{array}$ & $\begin{array}{c}2720 \\
8000^{+}\end{array}$ & $\begin{array}{l}3200 \\
8000^{+}\end{array}$ \\
\hline $\operatorname{mos}$ & $/ \mathrm{s} /$ & Final & $\begin{array}{l}\text { Min } \\
\text { Max }\end{array}$ & $\begin{array}{c}2220 \\
8000^{+}\end{array}$ & $\begin{array}{c}2360 \\
8000^{+}\end{array}$ & $\begin{array}{c}2480 \\
8000^{+}\end{array}$ & $\begin{array}{c}2560 \\
8000^{+}\end{array}$ & $\begin{array}{c}3160 \\
8000^{+}\end{array}$ \\
\hline rug & $|\mathbf{x}|$ & Final & $\begin{array}{l}\text { Min } \\
\operatorname{Max}\end{array}$ & $\begin{array}{c}800 \\
8000^{+} \\
\end{array}$ & $\begin{array}{c}760 \\
8000^{+} \\
\end{array}$ & $\begin{array}{c}2480 \\
8000^{+}\end{array}$ & $\begin{array}{c}2640 \\
8000^{+}\end{array}$ & $\begin{array}{l}2320 \\
6960\end{array}$ \\
\hline saag & $/ x /$ & Final & $\begin{array}{l}\text { Min } \\
\operatorname{Max}\end{array}$ & $\begin{array}{c}2460 \\
8000^{+}\end{array}$ & $\begin{array}{c}880 \\
8000^{+}\end{array}$ & $\begin{array}{c}2060 \\
8000^{+}\end{array}$ & $\begin{array}{c}2760 \\
8000^{+}\end{array}$ & $\begin{array}{l}2280 \\
7440 \\
\end{array}$ \\
\hline sag & $/ \mathrm{s} /$ & Initial & $\begin{array}{l}\text { Min } \\
\operatorname{Max}\end{array}$ & $\begin{array}{c}2180 \\
8000^{+}\end{array}$ & $\begin{array}{c}3200 \\
8000^{+}\end{array}$ & $\begin{array}{c}1080 \\
8000^{+}\end{array}$ & $\begin{array}{c}2800 \\
8000^{+}\end{array}$ & $\begin{array}{c}3320 \\
8000^{+}\end{array}$ \\
\hline saag & $/ \mathrm{s} /$ & Initial & $\begin{array}{l}\text { Min } \\
\operatorname{Max}\end{array}$ & $\begin{array}{c}1000 \\
8000^{+}\end{array}$ & $\begin{array}{c}3320 \\
8000^{+}\end{array}$ & $\begin{array}{c}1060 \\
8000^{+}\end{array}$ & $\begin{array}{c}2960 \\
8000^{+}\end{array}$ & $\begin{array}{c}3000 \\
8000^{*}\end{array}$ \\
\hline vaak & $/ \mathrm{f} /$ & Initial & $\begin{array}{l}\text { Min } \\
\operatorname{Max}\end{array}$ & $\begin{array}{c}2100 \\
8000^{+}\end{array}$ & $\begin{array}{c}3440 \\
8000^{+}\end{array}$ & $\begin{array}{c}3480 \\
8000^{+}\end{array}$ & $\begin{array}{c}1360 \\
8000^{+}\end{array}$ & $\begin{array}{c}3680 \\
8000^{+}\end{array}$ \\
\hline vuur & $/ \mathbf{f} /$ & Initial & $\begin{array}{l}\text { Min } \\
\operatorname{Max}\end{array}$ & $\begin{array}{c}1360 \\
8000^{+}\end{array}$ & $\begin{array}{c}3520 \\
8000^{+}\end{array}$ & $\begin{array}{c}1620 \\
8000^{+}\end{array}$ & $\begin{array}{c}2880 \\
8000^{+}\end{array}$ & $\begin{array}{l}3600 \\
7360\end{array}$ \\
\hline
\end{tabular}


At the 3-month and 6-month cochlear implant intervals, the subject's vocal duration was evaluated as being normal. As far as pausal duration is concerned, the listeners evaluated the use of pausal duration as being primarily longer than normal in the no-amplification and hearing aid conditions. At the cochlear implant 0 -month interval, two of the listeners rated the pausal duration as being normal, with the remaining listeners describing it as being either abnormally long or longer than normal. The pausal duration at the 3-month interval was evaluated by the majority of the listeners as being longer than normal. One listener judged it to be normal. At the 6-month cochlear implant interval, however, the subject's use of pausal duration was evaluated as being normal.

As can be seen in Table 8 , listener two was the only listener who differed from the other listeners. The Pearson Correlation Co-efficient and t-test was used in order to determine whether or not listener two differed significantly from the other listeners, i.e., one, three and four. These results indicated that there were no significant differences between the listeners ratings and that all the listeners ratings correlated significantly with one another.

\section{DISCUSSION}

\section{SPECTROGRAPHIC ANALYSIS}

\section{Suprasegmental features}

Prior to having the cochlear implant, it was noticed subjectively that the subject was inclined to increase his utterance length. The latter being a characteristic of profoundly deaf individuals, as noted by Nickerson, (1975). Taking this into account, it was expected that when utterance length was spectrographically analyzed, the results obtained with the cochlear implant would show a decrease in duration, when compared to the no- amplification and hearing aid condition. Results obtained from the evaluation of sentence duration (Table 1), however, did not at first yield any significant data. In fact, the mean values calculated for the cochlear implant condition were in all instances longer than the values obtained in the no-amplification situation, as well as the majority of values obtained during the hearing aid condition. These results are in direct contrast to the sentence duration characteristics of profoundly deaf individuals. These individuals tend to speak at a slower rate than what is considered normal speed, (Waldstein, 1990). The values measured were consequently compared with the spectrograms obtained for each of the sentences in the various auditory input situations. These comparisons indicated that the reason for the lower sentence duration values in the no-amplification situation and the higher sentence duration values in the cochlear implant situations was that in many instances the plosive release of final consonants of the last words spoken in the sentences were often omitted due to the absence of auditory feedback. The utterance length measured did therefore not include these omitted plosive portions of the consonants. This resulted in shorter sentence duration measurements. During the three cochlear implant intervals the subject was aware of these final consonants due to the improved speech information being provided by the cochlear implant as well as improved auditory feedback, and the subsequent production of these final consonants productions resulted in a measured increase in the utterance length.

As far as word stress (amplification) within the sentences is concerned, the use of the cochlear implant resulted in an increase in the highest relative amplitude peaks for stressed words when compared to the no-amplification and hearing aid situations (Table 2). The specific words within the sentences which were stressed remained consistent throughout all the auditory input situations. The relative amplitude peaks of these words increased as the subject was receiving increasing

Tabel 8. Rating scale for listeners' evaluation of pitch variation, vocal duration and pausal duration. results

\begin{tabular}{|c|c|c|c|c|c|c|}
\hline $\begin{array}{l}\text { Evaluation } \\
\text { parameters }\end{array}$ & Listeners & $\begin{array}{c}\text { No-Amplification: } \\
\text { Listeners } \\
\text { ratings }\end{array}$ & $\begin{array}{c}\text { Hearing Aid: } \\
\text { Listener } \\
\text { ratings }\end{array}$ & \begin{tabular}{|c|} 
Cochlear Implant \\
0-months: \\
Listener \\
ratings \\
\end{tabular} & $\begin{array}{c}\text { Cochlear implant } \\
\text { 3-months: } \\
\text { Listener } \\
\text { ratings }\end{array}$ & $\begin{array}{c}\text { Cochlear implant } \\
6 \text { months: } \\
\text { Listener } \\
\text { ratings }\end{array}$ \\
\hline $\begin{array}{l}\text { Pitch } \\
\text { Variation }\end{array}$ & $\begin{array}{l}\text { L. } 1 \\
\text { L. } 2 \\
\text { L. } 3 \\
\text { L. } 4\end{array}$ & $\begin{array}{l}1 \\
1 \\
1 \\
1\end{array}$ & $\begin{array}{l}1 \\
2 \\
1 \\
1\end{array}$ & $\begin{array}{l}1 \\
2 \\
1 \\
1\end{array}$ & $\begin{array}{l}2 \\
3 \\
2 \\
2\end{array}$ & $\begin{array}{l}3 \\
3 \\
3 \\
3\end{array}$ \\
\hline $\begin{array}{l}\text { Vocal } \\
\text { Duration }\end{array}$ & $\begin{array}{l}\text { L. } 1 \\
\text { L. } 2 \\
\text { L. } 3 \\
\text { L. } 4\end{array}$ & $\begin{array}{l}2 \\
2 \\
2 \\
2\end{array}$ & $\begin{array}{l}2 \\
2 \\
2 \\
2\end{array}$ & $\begin{array}{l}2 \\
2 \\
2 \\
2\end{array}$ & $\begin{array}{l}3 \\
3 \\
3 \\
3\end{array}$ & $\begin{array}{l}3 \\
4 \\
3 \\
3\end{array}$ \\
\hline $\begin{array}{l}\text { Pausal } \\
\text { Duration }\end{array}$ & $\begin{array}{l}\text { L. } 1 \\
\text { L. } 2 \\
\text { L. } 3 \\
\text { L. } 4\end{array}$ & $\begin{array}{l}2 \\
1 \\
2 \\
2\end{array}$ & $\begin{array}{l}3 \\
2 \\
2 \\
2\end{array}$ & $\begin{array}{l}3 \\
2 \\
1 \\
3\end{array}$ & $\begin{array}{r}2 \\
2 \\
2 \\
3\end{array}$ & $\begin{array}{l}3 \\
3 \\
3 \\
3\end{array}$ \\
\hline
\end{tabular}


amounts of intensity information via the cochlear implant. These alterations in loudness are coded by the multichannel cochlear implant as changes in current level, (Tobey \& Hasenstab, 1991). An individual's ability to make use of intensity variations within utterances prevents the tendency to become monotone and reinforces the normal patterns of intonation in speech, (IlerKirk \& Edgerton, 1983).

In terms of the pitch variations in $F O$, there appeared to be an over compensation in the use of varying fundamental frequency at the 3-month interval, with a slight decrease in variation at the 6 -month interval, resulting in a more normalized version of fundamental frequency variations. The subject was, therefore, at the 3-month interval beginning to perceive the increased spectral information being provided by the implant as well as the variations in $\mathrm{F} 0$ as coded by the stimulation rate delivered to a given channel, (Tobey \& Hasenstab, 1991). These variations in $\mathrm{F} 0$ were in turn providing increased suprasegmental information required in the use of questions, as was emphasizing certain words within a sentence in order to either alter the meaning of the sentence or emphasize a specific word within the sentence, (Iler-Kirk \& Edgerton, 1983). It is also interesting to note that the words in the sentences which were produced with the highest $\mathrm{F} 0$ pitch remained consistent throughout all the auditory input situations. These words produced with the highest F0 pitch were also the words produced with the highest amplitude peaks. These results indicate that the subject is utilizing the suprasegmental features of speech accurately with the aim of emphasizing a specific word in an utterance.

\section{Segmental features}

\section{- Vowels}

The overall decrease in vowel duration with the use of the cochlear implant is iconfirmed by the results obtained by Tartter et al., (1989) who also found a decrease in vowel length in a postlingually deafened individual during the first year of use with a multichannel cochlear implant. The decrease in vowel length can be attributed to the improved temporal coding mechanisms provided by the cochlear implant, which in turn, improve and enhance auditory feedback monitoring, implicated in regulating the phonetic precision of segmental and suprasegmental characteristics of speech, (Waldstein, 1990; Svirsky et al., 1992).

As far as the relationship between the vowel formant frequencies is concerned, the results of the F1 and F2 values across the various auditory input situations did not show any significant differences (Table 5 ). The relationship between the F1 and F2 values for the eight different vowels indicated that the vowel, productions across the various auditory input situations occupy well defined loci as expected. These results verify the minimal changes in the relationship between $F 1$ and F2 across the various auditory input situations, indicating relatively stable vowel productions. To further enhance the interpretation of these results, the mean F1 and F2 cochlear implant values were compared with the mean values obtained from normal hearing Afrikaans speaking male subjects, (Van der Merwe et al., 1993). The mean $F 1$ values obtained in the cochlear implant condi- tion for each vowel were consistently higher than the normal F1 values. Tartter et al., (1989) in their study indicated that their subjects exhibited lower values after a period of use with the cochlear implant. A possible explanation for the higher $F 1$ values obtained in the present study, could be attributed to the fact that the subject was not a standard Afrikaans speaker. Variations from the norm are often found when a dialect of a language is spoken, (Sommerstein, 1977). By taking the overall results into account, it can therefore be assumed that the subject's profound hearing loss did not result in deviant vowel productions.

\section{- Consonants}

With regard to the relative amplitude peaks for consonants in CVC word combinations across the various auditory input situations, the most significant increases in amplitude peaks were for the plosive sections of the stop consonants (Table 6). These significant increases in amplitude peaks can be interpreted in terms of the absence, in the first instance, of the plosive releases in the no-amplification situations for the consonants / $\mathrm{p} / \mathrm{l} / \mathrm{t} / \mathrm{and} / \mathrm{k} / \mathrm{as}$ well as the consonants / $\mathrm{p} / \mathrm{and} / \mathrm{k} /$ in the hearing aid situation, to the presence in the second instance of plosive releases for these consonants during the cochlear implant intervals. For the fricatives in the initial and final positions, the majority of amplitude peaks in either the 3- or 6-month cochlear implant conditions are higher than the amplitude peaks observed in the no-amplification or hearing aid conditions, indicating improved accuracy in consonant production. This can be attributed to two factors. In the first instance, the cochlear implant is providing increased spectral information which in turn allows the subject to perceive these consonants auditorily, thereby improving the auditory feedback mechanism of the subject's own productions, (Dorman, Soli, Dankowski, Smith, McCandless \& Parkin, 1990). In the second place, the cochlear implant is resulting in increased accuracy in the articulation of consonants, which consequently results in an increase in the intensity of the production.

The spectral frequency ranges of the plosive sections of the stop consonants during the 6-month cochlear implant interval did show a decrease in the frequency regions occupied for the majority of the productions when compared with the no-amplification condition. A decrease in frequency range is a direct result of a more concentrated release of the plosive section of the stop consonant, thereby improving the accuracy of productions. Minifie (1973), mentions that the noise bursts of the stop consonants are dependent upon the volumes within the vocal tract, which participate in resonance of the source energies. These volumes are primarily determined by the vocal tract occlusion. It can therefore be assumed that the more concentrated production of the plosive sections of the stop sounds, can be attributed to the correct placing of vocal tract occlusion. The latter is a result of the improved auditory feedback mechanisms provided by the cochlear implant itself. As far as the fricatives are concerned, the spectral noise bands with the cochlear implant at the 6-month interval also showed a decrease in the frequency ranges measured for each fricative when compared to the no- 
amplification situation. These spectral noise band limits measured for the fricatives fell within the noise band limits of normal speakers, (Baken, 1987). The majority of the fricatives showed an increase in the minimum frequency with the use of the cochlear implant. These findings resulted in a narrowing of the spectral noise band frequencies which once again indicated the concentration of energy as a result of marked vocal tract constriction, resulting in increased accuracy of fricative production (Minifie, 1973).

\section{- LISTENER ANALYSIS}

The results of the listener's rating of pitch variation indicated that the subject was beginning to use pitch and intensity information being provided by the cochlear implant. These results are supported by Iler-Kirk \& Edgerton, (1983); Dowell et al., (1985); Leder et al., (1986); and Tyler \& Kelsay, (1990), who also reported improvements in voice control with the use of a multichannel cochlear implant. These improvements can be attributed to the pitch information being provided by the cochlear implant resulting in improved auditory feedback of the subject's utterances. As far as vocal duration and pausal duration are concerned, the improvements which were made could once again be attributed to the improvements in auditory feedback resulting in improved voice control and temporal resolution, (Leder et al., 1986; Tyler \& Kelsay, 1990; Tartter et al., 1989). The latter improvements correlate well with the results obtained during the suprasegmental analysis.

\section{CONCLUSION}

In conclusion, the results of the spectrographic analyses indicated that the information provided by the cochlear implant resulted in the improved use of suprasegmental features by the subject. There was an overall decrease in sentence length resulting in less drawn out speech. For the sentences where there was an increase in sentence length, the presence of consonants in the final position during the cochlear implant intervals as opposed to the absence thereof during the no-amplification and hearing aid situations, provided a logical explanation for this occurrence. The use of increased word stress measured in terms of relative amplitude as well as an increase in the variation of fundamental frequency, typically resulted in less monotone and more variable speech production.

As far as the segmental features are concerned, the results of the vowel analysis indicated that the cochlear implant was providing improved auditory feedback which subsequently resulted in a decrease in vowel length over time. The relationship between the first and second formants for the various vowels did not show any significant differences across the various auditory input situations. These results were expected as the subject's vowel productions were not perceived as being deviant when subjectively compared to the same vowel productions by normal hearing individuals. The overall increase in relative amplitude peaks for the consonants investigated as well as the narrowing of the spectral frequency ranges and the spectral noise band frequencies indicated that the use of the cochlear implant was resulting in far more accurate consonant productions.

The results of the listener's analysis of speech production indicated that the multichannel cochlear implant confirmed a significant improvement in the use of suprasegmental features in the subject's speech production as perceived by the listeners. The overall improvement in the use of suprasegmental speech features can be attributed to the normalization in the use of pitch variation as well as vocal and pausal duration with the cochlear implant over time.

Finally, the "hearing" provided by the cochlear implant is considered to have two major roles in maintaining the communicative effectiveness of the production mechanisms in adults. In the first instance, self hearing helps to calibrate production mechanisms by monitoring relations between the implant user's own articulations and his/her acoustic output. In the second instance, the speaker can validate his/her acoustic output by observing the behaviour of the listeners and by detecting discrepancies between his own speech and that of the listeners, (Perkell et al., 1992).

\section{REFERENCES}

Baken, R.J. (1987). Clinical Measurement of Speech and Voice. Massachusetts: College-Hill Press, Inc.

Cochlear Pty Limited. (1989). Mini System 22: Audiologists Handbook. Sydney, Australia.

Cohen, N.L., Waltzman, S.B. \& Shapiro, W.H. (1985) Clinical trials with a 22-channel cochlear prosthesis: In Laryngoscope, 95: 1448-1454

Coles, L.D. (1990). The effect of certain suprasegmental features of the hearing impaired child's speech intelligibility. Unpublished Master's Thesis, University of Pretoria.

Cowie, R., Douglas-Cowie, E. \& Kerr, A.G. (1982). A study of speech deterioration in post-lingually deafened adults. In Journal of Laryngology and Otology, 96: 101-112.

Dorman, M.F., Soli, S., Dankowski, K., Smith, L., McCandless, G. \& Parkin, J. (1990). Acoustic cues for consonant identification by patients who use the Ineraid cochlear implant. In Journal of the Acoustical Society of America, 88: 2074-2079.

Dowell, R.C., Brown, A.M., Seligman, P.M. \& Clark, G.M (1985). Patient results for a multiple-channel cochlear prosthesis. In Schindler, R.A. \& Merzenich, M.M. (eds.): Cochlear Implants. New York: Raven Press.

Dowell, R.C., Seligman, P.M., Blamey, P.J.\& Clark, G.M (1987). Speech perception using a two formant 22-electrode cochlear prosthesis in quiet and in noise. In Acta Otolaryngology (Stockholm), 104: 439-446.

Economou, A., Tartter, V.C., Chute, P.M. \& Hellman, S.A (1992). Speech changes following reimplantation from a single-channel to a multichannel cochlear implant. In Journal of the Acoustical Society of America, 92: 1310-1323.

Eddington, D.K. (1983). Speech recognition in deaf subjects with multi-channel intracochlear electrodes. In Parkins, C.W. \& Anderson, S.W. (eds.): Cochlear Prosthesis: An international symposium, Annals of the New York Academy of Sciences, 405: 48-63.

Iler-Kirk, K. \& Edgerton, B.J. (1983). The effects if cochlear implant use on voice parameters. In Otolaryngologic Clinics of North America, 16: 281-292.

Lane, H. \& Webster, J. (1991). Speech deterioration in postlingually deafened adults. In Journal of the Acoustical Society of America, 89: 859-866.

Leder, S.B., Spitzer, J.B., Milner, P., Flevaris-Phillips, C. Richardson, F. \& Kirchner, J.C. (1986). Reacquisition of contrastive stress in an adventitiously deaf speaker using a single-channel cochlear implant. In Journal of the Acoustical Society of America, 79: 1967-1974.

Ling, D. (1976). Speech and the Hearing-Impaired Child: Theory and Practice, Washington, D.C.: The Alexander 
Graham Bell Association for the Deaf.

Minifie, F.D. (1973). Speech acoustics. In Minifie, F.D., Hixon, J.J. \& Williams, F. (eds.): Normal Aspects of Speech, Hearing and Language. Englewood Cliffs, New Jersey: Prentice-Hall, Inc.

Nickerson, R.B. (1975). Characteristics of the speech of deaf persons. In The Volta Review, 77: 342-362.

Perkell, J., Lane, H., Svirsky, M. \& Webster, J. (1992). Speech of cochlear implant patients: A Longitudinal study of vowel production. In Journal of the Acoustical Society of America, 91: 2961-2978.

Schindler, R.A., Kessler, D.K., Rebscher, S.J., Yanda, J.L. \& Jackler, R.K. (1986). The UCSF/STORZ multichannel cochlear implant: Patient results. In Laryngoscope, 96: 597603.

Sommerstein, A.H. (1977). Modern Phonology. Edward Arnold Publishers.

Svirsky, M.A., Lane, H., Perkell, J.S. \& Wozniak, J. (1992) Effects of short-term auditory deprivation on speech production in adult cochlear implant users. In Journal of the Acoustical Society of America, 92: 1284-1300.

Tartter, V.C., Chute, P.M. \& Hellman, S.A. (1989). The speech of a postlingually deafened teenager during the first year of use of a multichannel cochlear implant. In Journal of the Acoustical Society of America, 86:2113-2121.

Thielemeir, M.A., Eisenberg, C.S. \& Brimacombe, J.A. (1982) Audiological results with the cochlear implant. In Annals of Otology, Rhinology and Laryngology, 91, (Suppl. 91): 6266.

Tobey, E.A. \& Hasenstab, M.S. (1991). Effects of a Nucleus multichannel cochlear implant upon speech production in children. In Ear and Hearing, 12: 48-54.

Tyler, R.S., Gantz., B.J., McCabe, B.F., Lowder, M.W., Otto. S.R. \& Preece, J.P. (1985). Audiological results with two single-channel cochlear implants. In Annals of Otology, Rhinology and Laryngology, 94: 133-139.

Tyler, R.S. \& Kelsay, D. (1990). Advantages and disadvantages reported by some of the better cochlear implant patients. In The American Journal of Otology, 11: 282-288.

Van der Merwe, A., Groenewald, E., Van Aardt, D., Tesner, H.E.C. \& Grimbeek, R,J. (1993). Die formant-patrone van Afrikaanse vokale soos geproduseer deur manlike sprekers. In South African Journal of Linguistics, 11(2): 71-79.

Waldstein, R.S. (1990). Effects of postlingual deafness on speech production: Implications for the role of auditory feedback. In Journal of the Acoustical Society of America, 88: 2099-2114.

Appendix A. Rating scale for the listener's evaluation of pitch variation and vocal and pausal duration

\begin{tabular}{|c|c|c|c|c|c|c|}
\hline \multirow{5}{*}{ } & \multicolumn{6}{|c|}{ Description of feature as perceived by listener } \\
\hline & & 1 & 2 & 3 & 4 & 5 \\
\hline & $\begin{array}{c}\text { pitch } \\
\text { variation }\end{array}$ & monotone & $\begin{array}{c}\text { little } \\
\text { variation }\end{array}$ & normal & $\begin{array}{l}\text { too much } \\
\text { variation }\end{array}$ & $\begin{array}{l}\text { abnormal } \\
\text { variation }\end{array}$ \\
\hline & $\begin{array}{c}\text { vocal } \\
\text { duration }\end{array}$ & $\begin{array}{c}\text { abnormally } \\
\text { long }\end{array}$ & $\begin{array}{c}\text { longer } \\
\text { than } \\
\text { normal }\end{array}$ & normal & $\begin{array}{c}\text { shorter } \\
\text { than } \\
\text { normal }\end{array}$ & $\begin{array}{c}\text { abnormally } \\
\text { short }\end{array}$ \\
\hline & $\begin{array}{c}\text { pausal } \\
\text { duration }\end{array}$ & $\begin{array}{c}\text { abnormally } \\
\text { long }\end{array}$ & $\begin{array}{c}\text { longer } \\
\text { than } \\
\text { normal }\end{array}$ & normal & $\begin{array}{c}\text { shorter } \\
\text { than } \\
\text { normal }\end{array}$ & $\begin{array}{c}\text { abnormally } \\
\text { short }\end{array}$ \\
\hline
\end{tabular}




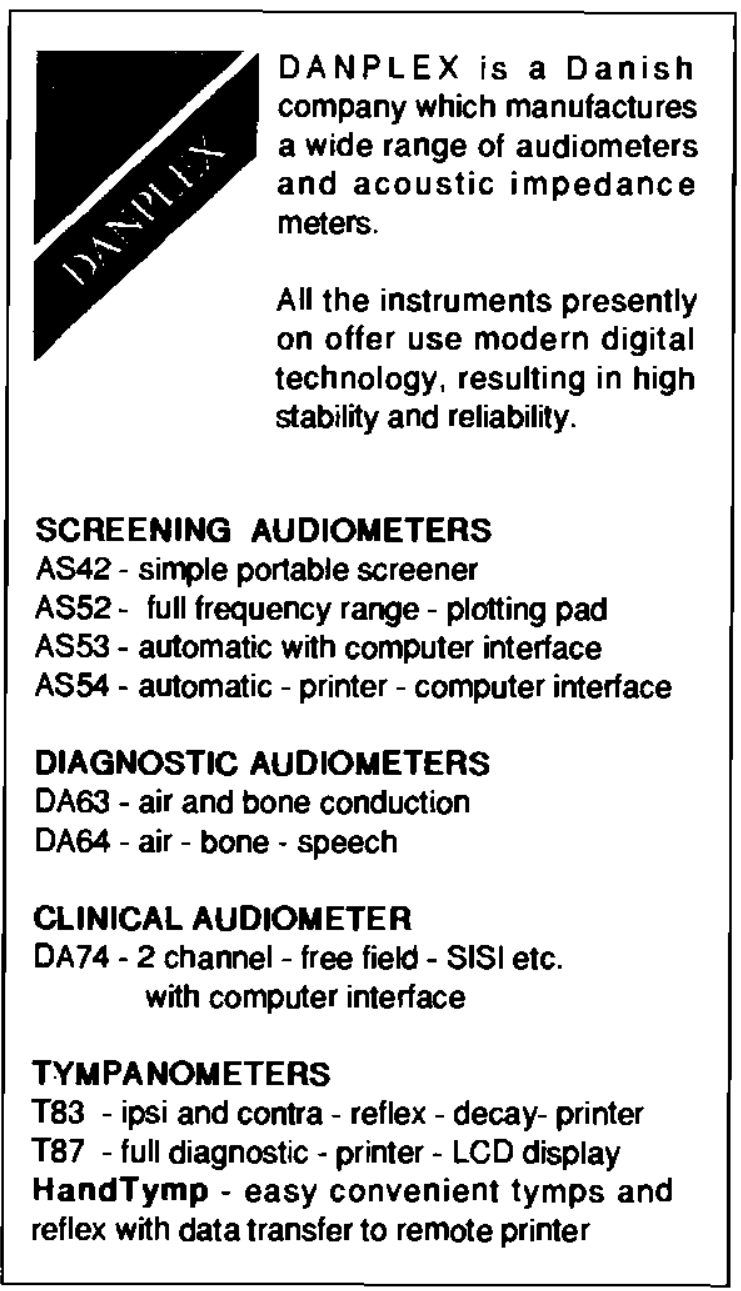

\section{JEDMED VIDEO OTOSCOPE}

Displays a very high quality video image of the ear examination for your patients and their family.

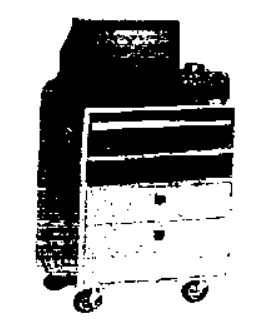

COLOUR prints for your records and referring doctors.
The Medical Instrument Division of Acoustimed specializes in equipment for the ENT and Audiology professions.

It is our policy to obtain the most modern instrumentation available and some of the equlpment is described here.

Please enquire about other items in our large range of diagnostic and surgical products.

\section{S.R. Electronics}

\section{Acoustic Rhinometers}

Acoustic Rhinometry provides accurate and objective measurement of the nasal cavities. Area, volume, minimum cross-sectional area, variance and mean are analysed by the computer.

Multiple displays can be printed and saved in a database with patient data.

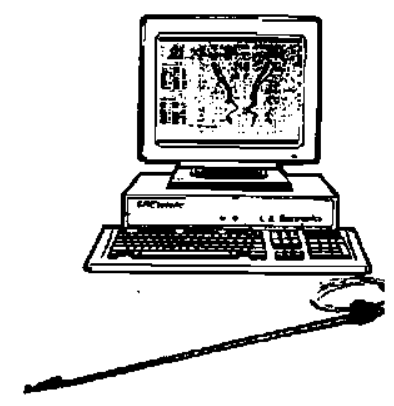

The RHIN 2000 instruments provide objective indication of an oblique nasal septum, swollen mucosa or blocking polyps. Snoring, pulseoxymeter and allergen packages (including olfactometry) are optional.

\section{JEDMED INFRA-RED VIDEO ENG}

Uttra small video cameras with computer imaging technology provide continuous observation and video recording of eye movement for 4-channel, direct coupled vestibular analysis.

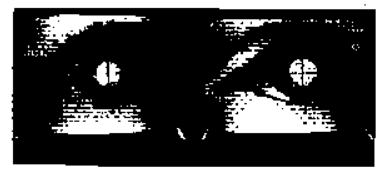

COMPLETE ENG WITHOUT ELECTRODES

Electrode Free - Noise Free ENG's

No Calibration - Faster Testing

Eyes Open - More Reproducible Tests

Spontaneous Tests - Positional Tests - Hallpikes

Caloric Tests - Rotational Tests - Nystagmus Monitor

Hor. and Vert. Tracking - Gaze - Saccades

\section{ACOUSTIMED (Pty) Ltd.}

74 Third Ave. Melville, Johannesburg - P.O. Box 909. Auckland Park; 2006 Telephone: (011) 482-3085 Fax: (011) 726-2430 